\title{
Human and Nature Nexus
}

Raju Chitrakar

Lecturer in English, Padma Kanya Multiple Campus, Tribhuvan University, Kathmandu, Nepal

'Human being is the master of nature,' is the long established axiom. This paper presents contrary argument from this. It claims that as human being is not master of nature, but one of its member species, and hence is subservient to it. The sooner humans understand this, and mould their conducts accordingly, the more they are likely to get peace, stability and development in the true worth. Hence, humans have to establish coping relationship with nature, not dominating one.

To achieve the goal of establishing human and nature nexus, I first bring a case of the destruction of nature in Nepal and its side effects to the villagers. Then I present historical context of human and nature relationships. After that alternative ecocentric practices are presented. I draw conclusion from these.

\section{A Case of the Destruction of Nature in Nepal}

In eastern Surkhet, there is a hilly settlement called Kanda Ghuwani. Around sixty years ago, the village was only in the middle of the western slope. There was a big forest in the upper slop of the hill and it was saved as people would hardly enter into it being afraid of frequent approach of bears, tigers, and other animals. They did not have any problem of fire wood, fodder for cattle, and most importantly oozing of water here and there. However, poachers eliminated the animals without knowing it from the whole vicinity. Rampant destruction of the forest started then after. Their hardship days also increased little by little. Sensing that they are bound to leave their loving village sooner or later, many villagers have already shifted to other places. "Why did you leave the village?" I asked one. He replied, "It would take whole morning to bring one jar of water and whole day to bring one basket of firewood or fodder. It would also finish soon. What to do then. I did it earlier." They may not even have guessed why had to face such a fate.

This is a representative case of many other villages of Nepal and other parts of the world. We often hear such stories. And this is a perfect example of what happens to humans whey they make adverse relationship with nature. As the people of Kanda Ghuwani finished their forest, they are also going to be finished soon. And such will be the fate of many other villagers of Nepal. As urban people have no contact with nature, they are facing other environmental problems like pollution, chemical reaction, lack of fresh water, air, and space, and chronic 
diseases like pressure, sugar, cancer, and the like. As the destruction of nature has still been increasing, environmental problems have been increasing too. Unless some remarkable steps have not been taken immediately, it will accelerate, which means increasement in the suffering of people.

\section{Historical Context of Human and Nature Relationship}

Dominant world view has been occidental for millennia. Western principles of life and literature have dominantly remained logo centric. Up to the middle ages, God was the center. Selected men, Popes, ruled in the name of being messengers of God. With the renaissance, the focus gradually shifted to purely human beings: fulfillment of human gratification became the center of focus. However, faith in the human unlimited capacity started to crack from the Victorian and the modern periods and totally crumbled until the Second World War. So tragedy became its note. The post-modern period remained totally baffled or disillusioned with the sense of losing the centre. Even literary criticism also could not cross the boundary of human sphere. Jacques Derrida deconstructed the very assumption of human language's ability to hold truth. So did Julia Christiva. John Lacan showed un-decidability of human mind. Cheryll Glotfelty writes, "Despite their "revisionist energies" the modern and postmodern literary scholarship appeared to have been "unaware of outside natural world" (xv). Political and dominant social practices have also dominantly remained human affairs. In this way, human world has moved between the author or authority, reader or people, and the conscious or unconscious human world.

However, there has appeared environmental criticism, also known as ecocriticism, since 1980s. It studies human and nature relationship in the human history. It finds three consecutive developments in the human and nature relationship: strong anthropocentrism, weak anthropocentrism -as divided by Byran G. Norton (156), and ecocriticism, first proposed by William Rueckert in 1978 (Glotfelty xx). First two are the variations of anthropocentrism and the last one is their anti-thesis.

Strong anthropocentrism works mainly with two assumptions. The first is an assumption that human role is to have dominion over or make use of the infinite cornucopian nature as licensed by Greco-Roman and Judeo -Christian traditions, which took that nature is made for human being, and which generated the philosophy and tradition of hierarchy and difference. "Christianity is the most anthropocentric religion the world has seen" (Lynn White, Jr. 34). The second is the assumption that human capabilities can overcome environmental challenges. Thus, axiom of the strong anthropocentric world view is that 'the more human beings use nature the more they develop.' As a result, human being has made 
unrestrained use of nature throughout its long anthropocentric history and hence the prefix 'strong' before anthropocentrism. Discourses of strong anthropocentrism tend to show potential positive human outcomes extended by economic modes.

Unlike strong anthropocentrism, weak anthropocentrism takes nature finite or limited, not infinite or unlimited. So it pleads to make restrained use of nature. Ecological discourses articulate the undesirable outcomes from the strong anthropocentric relationships of dominance over the environment. Environmental writers like Rachel Carson and Paul Ehrlich have shown apocalyptic or deteriorating effects on humanity caused by environmental damage. Similarly, Barry Commoner and Al Gore have challenged the models of growth and expansion and highlighted the downside of dominance over nature. They have expressed the views that if we follow the ecological principle of equilibrium and take action to reduce further damage, harmony with nature might still be created. Ecocritics take such an awareness of stewardship or care for nature as 'weak anthropocentrism' as it poses some restriction on the free use of nature. However, it somehow holds human privilege over nature: it assumes that human being can and has to keep balance with nature for human benefit. It adopts conservationist notion that humans should both conserve and utilize nature.

However, 'ecocriticism' moves far beyond the position even that of weak anthropocentrism. It started in the US in the 1980s and in the UK in the early 1990s. It holds non-anthropocentric stand and applies holistic approach. According to Greg Garrard, "Indeed, the widest definition of the subject of ecocriticism is the study of the relationship of the human and the non-human, throughout human cultural history and entailing critical analysis of the term 'human' itself" (5). Similarly, in The Environmental Imagination: Thoreau, Nature Writing, and the Formation of American Culture, Lawrence Buell makes a "checklist" of four points that characterize the nature of environment oriented work: "The nonhuman environment indicates that human history is implicated in natural history; the human interest is not the only legitimate interest; the ethical orientation of a text is based on human accountability to the environment; environment is a process rather than as a constant or a given" (6-8). Ecocritics diminish any kind of hierarchy between human being and nature. There are subtle differences between the weak anthropocentric caretaker role and the ecocenric or holistic visionary: "the caretaker stands apart from nature in a spectator role, whereas the holistic/ harmonic mode of perception involves an aesthetic and mystical awe, plus a feeling of oneness with all of nature -the experience of the sublime (Lenz 160). So ecocritics share the environmental sensibilities such as land ethic, deep ecology, theories of intrinsic value, changed understanding of environmental aesthetics, and ecofeminism. All these contribute one way or other 
to the ecocritical position which holds the fact that "long term health of the biosphere should take precedence" (Botzler \& Armstrong 410). It adopts preservationist notion, that nature should be given a total freedom.

\section{Alternative Ecocentric Practices in the Present}

Most of the ecocritical writings and practices are taken as 'green radicalism.' Mainly ecofeminists, deep ecologists, bioregionalists, eco-socialists, green economists, green parties come under this term. John Dryzek divides green radicalism into two categories: one that focuses on changing consciousness. And another that looks more explicitly to green politics.

A stress on green consciousness has the conviction that the way people experience and regard the world in which they live is the key to green change. Once conscious has changed to appropriate direction, then politics, social structures, institutions, and economic systems are expected to come to the track of green. Deep ecologists, ecofeminists, bioregionalists and ecotheologists come to this group as they plead for green consciousness.

Deep ecology emphasizes self-realization and biocentric equality. "Selfrealization means identification with a larger organic "Self" beyond the individual person" (Dryzek 187). Ecofeminists take androcentrism as the root of environmental and female problems. The whole effort of ecofeminists is to bring a radical change in the mentality of males so that both women and nature are not suppressed. Bioregionalism cultivates a sense of place. People who live in a bioregion need to adopt and treat it as their home so that the region in turn can sustain human health and life. Bioregional consciousness implies a kind of ecological citizenship. Aldo Leopold's version presented in "The Land Ethic" is worth quoting here. He writes; "In short a land ethic changes the role of Homo sapiens from conqueror of the land-community to plain member and citizen of it. It implies respect for his fellow-members, and also respect for the community as such" (428). Ecotheologists see ecological problems in spiritual terms and think that if the root of the problem is spiritual, so too must be the cure. They take St Francis of Assisi as the patron saint of ecology as he was the first thinker who took nature equal to human being.

Other greens are more direct. They include green parties, social ecologists, environmental justice, and anti-globalization activities. These come under green politics group. They find conventional form of organization in political parties. Green parties have made their visible appearance in the countries like Belgium, the Czech Republic, Finland, France, German, Ireland, and Italy. The German Greens parties Realo and Fundi have occupied remarkable position in the national politics. 
Social ecology is associated with Murry Bookchin. For him, hierarchy is the root of all evil in human society and human relationship with nature. Further, nature is not survival of the fittest but a cooperative place, a model for human society. Thus, he takes small-scale, mostly self-sufficient local communities existing in harmony with their neighbors and with their local environment as the alternative of hierarchy and competition associated capitalism. Similarly, transition towns and new materialism are a movement of local initiatives as a reaction to the failure of national governments and global negotiations in confronting climate change. The movement promotes self-sufficiency, energy conservation, greenhouse gas emissions reduction, resilience in the face of environmental threats. Transition towns manifest a new, sustainable materialism concerned with how people relate to resources and nonhuman nature. Likewise, environmental justice movement is concerned with the degree to which the environmental risks generated by society fall on the poor and ethnic minorities. Initially the movement focused to the risks caused by toxic dumps, "but concern soon broadened to encompass nuclear facilities, waste incinerations, air and water pollution" (Dryzed 213). The movement opposes the risk management paradigm seeking instead to prevent the generation of risk.

These ecocentric practices have not been worldwide phenomenon. They are limited to certain group or sectors of some developed countries. As ecocentrism is a new approach, its notions are least heard and applied globally. Developed countries have adopted weak- anthropocentric world view. They practice stewardship role to nature. They manage their forest. Their popular slogan is "sustainable development." But they are harming the world another way. They are polluting the environment from their industrial production and widespread use of pesticides. There are frequent nuclear tests from both super powers and other countries. There is perpetual fear of third world war. The world is not yet free from environmental catastrophe and apocalyptic possibility.

As in most of the poor and underdeveloped countries, Nepal appears to be practicing strong-anthropocentric notions. Most of the local people never lose opportunity to exploit nature whenever they get chance, be it killing a dear, chopping a tree for log, or polluting the environment by throwing litter wherever they fancy. Some people freely keep saw mill in the forest. Surprisingly, government does not see them. Government managers make big plans to destroy forest with their intent of personal and political benefit. In Sagarnath, Ratuwamai, Kohalpur Forestry Development Projects, all precious sal trees were felled and other fast growing soft wood plants were planted, which are also being destroyed. Government has now decided to build Nijgad International Airport by destroying around two and half millions of big and small trees of Nijgad located in Bara 
district. Its side-effects to animals, plants as well as to people are immeasurable and these are minimized by the planners. Nearby Simara, Janakpur or Biratnagar airports can easily be developed to fulfill the need of International Airports. So intent of the politicians and high officials is easily understood. It is speculated that from such strong anthropocentric activities of Nepalese government and people, remained 25 percent forest will be reduce to 20 or I5 percent very soon.

\section{Conclusion}

Let me make penultimate conclusion first. If you think that nature is made for human use, you are strong anthropocentric or an id-centric. Fulfillment of your gratification by any means is your ultimate aim. Nature has kept carnivorous species in a limited number because of their aggressive nature. So will be your fate: make many your victims and be victim of the same web. Likewise, if you think that nature has to be conserved for human benefit, you are weakanthropocentric, an ego-centric. You try to keep balance in things but you are ultimately failed as your motif of gratification is rooted in it. At critical times you will be further more dangerous than the strong-anthropocentric one. The world has been deceived time and again from the persons like you. Unlike these, if you think that you are the part of nature, you are an ecocentric, a super-ego-oriented. You don't have any sense of ego. You have dissolved yourself into all the living and non-living things of the world: you are human in look but mentally and practically you are earthly. You love all earthly things. You feel deserted in the desertion of others. Safety of the world is limited only on this. There is no threat to any of the world from the people like you. Real peace, freedom, stability, and development are appear only then.

In conclusion, dominant world views of human and nature relationship are still strong and weak anthropocentric. Both are human centered. Most people do not realize that they are part of nature. They take themselves different not only from nature but also from other individuals. As a result, both nature and humans are equally threatened from the human strong and weak-anthropocentric arrogance.

Solution is very simple and easy: shift your anthropocentric world views to non-anthropocentric, that is ecocentric one with the view that all elements of the world are one in substance, and hence, any damage to one element is damage to yourself. Nature is not a matter to exploit. Instead, it is one to harmonize with. Such a view, not only gives a total freedom to nature, but also offers a lasting chance for human beings from which they might be able to turn the present terrific world to a peace, loving, stable and developed world. Being intellectuals 
of ecocritical or environmental philosophy, we have a responsibility to solve the environmental problems of Nepal as a part of the world. There is no any strong nature defending body in the case of Nepal. We could fulfill it by forming one in this holy occasion of environmental pilgrimage to one of the few remained lap of nature, Chitwan national park.

\section{Works Cited}

Bookchin, Murry. The Modern Crisis. New Society, 1986.

Botzler, R. G. and S. J. Armstrong."Ecocriticism." Environmental Ethics: Divergence and Convergence. Eds. R. G. Botzler and S. J. Armstrong. $2^{\text {nd }}$ ed. McGraw Hill, 2005, pp. 408-411.

Buell, Lawrence. The Environmental Imagination: Thoreau, Nature Writing, and the Formation of American Culture. Harvard UP, 1995.

Carson, Rachel. Silent Spring. A Mariner Book Hughton Mifflin Company, 2002.

Commoner, Barry. The Closing Circle: Nature, Man and the Technology. 2ne ed. Alfred A. Knopf, 1972.

Dryzek, John. S. The Politics of the Earth: Environmental Discourses. 3rd ed. OxfordUP, 2013.

Ehrlich, Paul. The Population Bomb. Ballantine, 1968.

Garrard, Greg. Ecocriticism. First Indian print. Routledge, 2007.

Glotfelty, Cheryll. "Introduction: Literary Studies in an Age of Environmental Crisis." The Ecocriticism Reader: Landmarks in Literary Ecology. Eds. Cheryll Glotfelty and Harold Fromm. Georgia UP, 1996, pp. xv-xxxvii.

Gore, Al. Earth in the Balance: Forging a New Common Purpose. Earthscan, 1992.

Lenz, M. "Am I my Planet's Keeper? Dante, Ecosophy and Children's Books." Literature Association Quarterly, 19.4 (1994/95): 159-164.

Leopold, Aldo. A Sand County Almanac. OxfordUP, 1966.

Norton, Bryan. G. "Environmental Ethics and Weak Anthropocentrism." Environmental Ethics: An Anthology. Andrew Light Holmes Rolston III. Backwell Publishing, 2003, pp. 163-174.

White, Lynn, Jr. "The Historical Roots of our Ecological Crisis." Ecocriticism: The Essential Reader. Ed. Ken Hiltner. Routledge, 2015, pp. 29-46. 